for Philosophy of Religion 
European Journal for Philosophy of Religion (EJPR) is a peer-reviewed international journal devoted to the philosophy of religion and philosophical theology. It encourages discussions among scholars representing different philosophical and theological orientations within these fields of research. EJPR is edited at Innsbruck University, in partnership with the John Hick Centre for Philosophy of Religion at the University of Birmingham (UK) and published in cooperation with the Innsbruck Center for Philosophy of Religion The European Society for Philosophy of Religion, the British Society for Philosophy of Religion, the Society of Christian Philosophers (USA), and the Australasian Philosophy of Religion Association are well represented in the journal's Editorial and Advisory Boards.

\section{EDITORIAL BOARD}

Editor-in-Chief Janusz Salamon, Charles University, Prague

Co-Editor Graham Oppy, Monash University, Melbourne

Deputy Editor Georg Gasser, University of Innsbruck

Managing Editor Marco Benasso, University of Innsbruck

Review Editor Ryan Byerly, University of Sheffield

Associate Editors Anna Abram (United Kingdom) Godehard Brüntrup (Germany) David Cheetham (United Kingdom) John Martin Fischer (USA) Philip J. Ivanhoe (Hong Kong) Winfried Löffler (Austria) Dariusz Łukasiewicz (Poland)

\section{EDITORIAL CORRESPONDENCE}

\section{Georg Gasser}

deputy.editor@philosophy-of-religion.eu

\section{SUBSCRIPTION REQUESTS}

Marco Benasso

managing.editor@philosophy-of-religion.eu

Yujin Nagasawa (United Kingdom) Andrew Pinsent (United Kingdom) Roger Pouivet (France)

Thomas Schärtl (Germany)

Daniel von Wachter (Liechtenstein)

Oliver Wiertz (Germany)

\section{BOOKS FOR REVIEW}

T. Ryan Byerly

review.editor@philosophy-of-religion.eu

Department of Philosophy

University of Sheffield

45 Victoria Street

Sheffield S3 7QB

United Kingdom

ADVISORY BOARD

Chair Richard Swinburne

Mdan

Robert M. Adams

Michaty

Sébastien Billoud

Sophie-Grace Chappell

Francis X. Clooney

Richard Cross

Mark Csikszentmihalyi

Ingolf Dalferth

Thomas P. Flint
Jerome Gellman R. William Hask Paul Helm

Daniel Howard-Snyder

Peter van Inwagen

Jonathan L. Kvanvig

Brian Leftow

William E. Mann

Tim Mawson

Paul K. Moser

Guoxiang Peng

Howard Robinson
Thomas M. Schmidt Thomas D. Senor Mikael Stenmark Vladimir K. Shokhin Eleonore Stump Edward Wierenga Keith E. Yandell Dean Zimmerman William J. Wainwrigh Linda Zagzebski

DOI: $h t t p s: / / d x . d o i . o r g / 10.24204 / e j p r . v 9 i 1$

\section{INFORMATION FOR AUTHORS}

EJPR is published quarterly (March, June, September, December). A publication delay of one month is rare but possible. Approximately 40 scholarly articles are published each year. Authors should submit

https://philosophy-of-religion.eu/submission/

Manuscripts must not have been published previously or be under consideration for publication elsewhere. They must be ready for blind review and bear no trace of the author's identity. For more information about the submission process, please see our submission guidelines.

Length

Articles should not normally be longer than 9,000 words, including abstract, footnotes, and references

Articles must be prefaced by an abstract of approximately 100 words.

Texts to be published in the Discussions and Replies section must not exceed 4,000 words.

Reviews of books should not normally be longer than 2,000 words.

Evaluation Policy

Accepted work is typically published within one year of acceptance.

Suggestions for revision will be sent to the authors of the papers recommended for publication. In the interest of speed reviewers may give brisk verdicts for the Editor's eyes only, hence the Editor is not obliged to share the content of the report with the author whose paper has been rejected unconditionally.

SUBSCRIPTIONS (4 issues over one year, postage included)

Subscription rates are intentionally kept very low to enable subscription by institutions and scholars with limited budgets and to facilitate a wide distribution of the journal.

Institutional (print \& online): $140 \mathrm{EUR}$

Institutional online only: $110 \mathrm{EUR}$

Institutional online only (developing countries): 50 EUR

Personal print \& online: 100 EUR

Personal online only: 60 EUR

Personal online only (developing countries): 25 EUR

Individual issue (print): 48 EUR per copy

Individual issue (PDF): 38 EUR

Individual article (PDF): $18 \mathrm{EUR}$

Subscription requests should be sent to: managing.editor@philosophy-of-religion.eu

Access the full archive at:

https://philosophy-of-religion.eu/archive

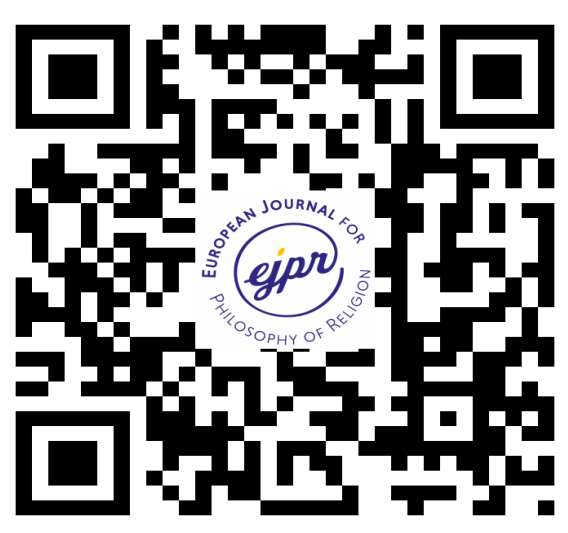




\section{EUROPEAN JOURNAL FOR PHILOSOPHY OF RELIGION}

VOLUME 9

NUMBER 1

SPRING 2017

\section{ARTICLES}

William MANDER

On the Consistency of Pantheism 1

Daniel CAME

Theism and Contrastive Explanation.

Aaron RIZZIERI

The Practice of Assertion under Conditions of Religious Ignorance

Moti MIZRAHI

Skeptheism: Is Knowledge of God's Existence Possible?

Roslyn WEISS

Waiting For Godo... And Godan:

Completing Rowe's Critique of The Ontological Argument. 65

R. Scott SMITH

Craig's Nominalism and the High Cost Of Preserving Divine Aseity

Daniel SAUDEK

Miracles and Violations of Laws of Nature

W. Matthews GRANT

Moral Evil, Privation, and God

Jeremy W. SKRZYPEK

A Better Solution to the General Problem of Creation 
Jonathan C. RUTLEDGE

An Epistemological Corrective to Doctrines of Assurance. 163

Ryan M. PARKER and Bradley RETTLER

A Possible-Worlds Solution to the Puzzle of Petitionary Prayer

\section{DISCUSSIONS AND REPLIES}

Jeffrey JORDAN

Divine Hiddenness and Perfect Love.

J. L. SCHELLENBERG

Response to Jordan 203

\section{BOOK REVIEWS AND NOTICES}

Robert MacSwain, Solved by Sacrifice: Austin Farrer, Fideism, and the Evidence of Faith

Reviewed by Sergio Sorrentino

Kevin Timpe, Free Will in Philosophical Theology

Reviewed by Benjamin Matheson

Aaron Rizzieri, Pragmatic Encroachment, Religious Belief and Practice

Reviewed by Martin Smith.

Brian Leiter, Why Tolerate Religion?

Reviewed by Jakub Urbaniak.

Patrick McNamara, The Neuroscience of Religious Experience.

Reviewed by Raymond Aaron Younis 


\title{
AN EPISTEMOLOGICAL CORRECTIVE TO DOCTRINES OF ASSURANCE
}

\author{
JONATHAN C. RUTLEDGE
}

UNIVERSITY OF ST ANDREWS

\begin{abstract}
Many Christian traditions affirm a doctrine of assurance. According to this doctrine, those who are saved have assurance of their own salvation; that is, the doctrine of assurance tells us that the elect can know their status as elect. In this paper, I explore two developments of the doctrine of assurance by theologians (i.e. John Calvin \& Kenneth Keathley) and argue that they fail to accommodate the fallibilistic nature of human knowing. I then develop a fallibilistic doctrine of assurance, which makes such assurance available to most Christians, and respond to an objection from the camp of pragmatic encroachment.
\end{abstract}

\section{INTRODUCTION}

Many Christian traditions have affirmed variations on a doctrine of assurance. According to this doctrine, those who are saved have assurance of their own salvation; that is, the doctrine of assurance tells us that the elect ${ }^{1}$

1 The term 'elect' can be either referential or attributive, and both senses are used here. The noun 'elect' picks out the set of persons who, roughly, possess the property of having been elected by God to reap the benefits of some sort of salvation. Salvation in Christian theology tends to be taken to refer to some sort of rescue from the evils of this world to a heavenly paradise. Variations on soteriology (i.e. doctrines of salvation) then will differ with respect to (i) what evils God's creation will be rescued from, (ii) the mechanics of such a rescue, and (iii) 
can know their status as elect. Historically, however, Christians who have belonged to traditions affirming the doctrine of assurance have testified to the seemingly fleeting nature of such assurance. Consider, for instance, John Bunyan's self-description in his own struggle to find assurance:

So I continued [this search for assurance] at a great loss; for I thought, if they only had faith, which could do so wonderful things, then I concluded that for the present I neither had it, nor yet for the time to come were ever like to have it. I was tossed betwixt the devil and my own ignorance, and so perplexed especially at some times, that I could not tell what to do. ${ }^{2}$

Bunyan certainly seems dissatisfied in this passage with the state of his so-called assurance. He doesn't know what to do; that is, how to acquire knowledge of his salvation. And he has not been alone. Such dissatisfaction has commonly reemerged for many professed Christians who have hoped to acquire a settled knowledge of their eternal security. Such persons covet the conviction of the Apostle Paul who wrote:

I know whom I have believed, and I am convinced that he is able to guard until that Day what has been entrusted to me (2 Timothy 1:12 ESV)

How did Paul arrive at such assurance in this passage ${ }^{3}$ Perhaps he had high-quality evidence for his own salvation which far surpasses the quality of evidence possessed by most believers today. However, while I would be willing to concede that Paul's evidence was of a better quality in general than most Christian believers, I doubt the difference in the quality of evidence is a significant obstacle to acquiring assurance of one's status as a member of God's family. In fact, I think such assurance is widely available

the nature of the heavenly realm, whether it be simply a renewal of the earthly and heavenly realm, something more ethereal akin to a Plato-like world of spirits, or a minimal view that takes perfect union with the divine as interchangeable with heaven.

2 John Bunyan. Grace Abounding to the Chief of Sinners, 26. Italics mine.

3 Although there are other passages, such as Hebrews 6:4-6, which indicate the possibility of losing one's salvation, I will not be discussing them here. There are important and interesting questions concerning the possibility of losing one's salvation, as well as whether these possibilities may nevertheless be all non-actual. See Kenneth Keathley, Salvation and Sovereignty (Nashville, TN: B\&H Publishing Group, 2010) chapter 6 for an accessible discussion of various positions in this debate. 
to most Christians. What really stands in their way is an epistemic, rather than a moral or practical, hurdle. ${ }^{4}$

In this paper, I will argue that assurance of salvation is available to professing Christians. What I will mean by assurance, however, will reflect the current state of analytic epistemology. Assurance is, after all, an epistemic concept since it concerns knowledge of one's own salvation. I will argue, then, that the best understanding of a doctrine of assurance operates on the assumption that one's knowledge is fallible, rather than infallible or absolutely certain.

While my construal of the doctrine of assurance will explain how it is possible for us to have knowledge of salvation, it will not by itself explain the phenomenon highlighted above; namely, that many Christians consciously worry about their status as elect or non-elect. Fortunately, I have a plausible and brief explanation for this. I think the sort of existential crisis of faith exhibited by those who fret about their salvation is just a special instance of the existential crisis one faces when one realizes infallible knowledge is unattainable for creatures like us. Learning of the epistemic limitations of humanity in this way, especially when faced with skepticism, can be worrisome. But on the whole, a healthy dose of skepticism is good for the human soul.

I will proceed as follows. In section 2, I will introduce some important concepts and distinctions in contemporary epistemology that will be necessary for understanding the doctrine of assurance. Once I have done this, we will look briefly in section 3 at John Calvin's understanding of assurance,

$4 \quad$ Philosophy of religion, with which many contemporary readers will be familiar, has largely embraced the camp of Reformed Epistemology, the best-known defense of which can be found in Alvin Plantinga, Warranted Christian Belief (Oxford: Oxford University Press, 2000). What I have to say in this paper is consistent with much of Plantinga's account, if for no other reason than that Plantinga's religious epistemology focuses on questions of warrant (i.e. that property enough of which turns true belief into knowledge) while I want to discuss the status of our epistemic justification or rationality subsequent to our reflection on our evidence and epistemic standards. Though not entirely unrelated, these two projects are importantly different. For the most thorough development of the sort of view I'm interested in defending, see Jonathan L. Kvanvig, Rationality and Reflection: How to Think About What to Think (Oxford: Oxford University Press, 2014). To see the fruit of such an epistemology applied to issues in contemporary philosophy of religion (e.g. skeptical theism and the problem of evil), see Jonathan Curtis Rutledge, "Commonsense, Skeptical Theism, and Different Sorts of Closure of Inquiry Defeat," Faith and Philosophy 34.1 (2017), 17-32. 
followed by a more recent statement of the doctrine by theologian Kenneth Keathley. Both of these statements, the classic and the contemporary, similarly suffer from a failure of attention to distinctions in the theory of knowledge. I will take them, then, in section 4 as a foil for my own understanding of assurance that corrects this oversight. Once I have presented my account, I will conclude in section 5 by responding to an objection from the epistemological camp of pragmatic encroachers - i.e. philosophers who claim that there is a condition on knowledge dealing with pragmatic stakes. In short, such philosophers argue that (roughly) as the practical importance of knowing something increases, the more difficult it will be to know. And since salvation is of infinite importance, knowledge of one's salvation is pretty much impossible. As I will argue, this objection fails because it incorrectly locates the epistemic effects of practical stakes in the nature of knowledge. Pragmatic concerns do not have to do with whether or not one knows, but rather, with whether such knowledge is actionable. Let us, then, turn first to some important distinctions in epistemology.

\section{FALLIBILISM AND LEVELS CONFUSION IN EPISTEMOLOGY}

The standard view of the nature of knowledge is that knowledge is composed of justified true belief. ${ }^{5}$ In other words, for something to count as a state of knowing, it must be a belief, it must be true, and it must be justified. While each of these conditions on knowledge could profitably be expanded upon, I will constrain my discussion to the best construal of justification.

Justification of the sort necessary for knowing $p$ requires that (J1) one's evidence supports $p$ to some significant extent and (J2) one bases one's belief that $p$ on the evidence one has for $p$. The first significant epistemological distinction for our purposes rests on the degree of support required by (J1) above.

Descartes notoriously places the degree of support necessary to satisfy (J1) incredibly high by requiring that the connection between one's evidence

5 See Richard Feldman, Epistemology (NJ: Prentice Hall, 2003). Also, despite this being the "standard" view, it's well-known amongst philosophers that JTB is insufficient for knowledge. I'll assume doxastic justification is necessary for knowledge and simply note that a no-defeat condition and non-Gettiered condition will get us the rest of the way to knowledge. 
and the propositions one justifiably believes on the basis of that evidence to be infallible. ${ }^{6}$ The search for a foundation of knowledge which infallibly guarantees a connection with truth, however, has unfortunately remained elusive. And even if there were some small set of propositions (e.g. thinking entails my existence) for which such infallibility might be attainable, that set would be so small as to make infallible knowledge in general a vain pursuit. Thus, epistemologists, by and large, have moved on from the Cartesian project of infallibility and adopted a fallibilist conception of knowledge, which corresponds with a fallibilist construal of justification.

The fallibilist notion of justification famously proceeds on the assumption that while the following sentence expresses an impossible proposition,

I know for certain that $p$, although I might be wrong about $p$.

sentences such as,

I know that $p$, although I might be wrong about $p .{ }^{7}$

are entirely coherent. The difference between these two Moorian sentences is that the former claims the presence of infallible knowledge by way of the locution 'for certain', whereas the latter makes no such claim. The intended point, then, is that it is possible for us to be justified in our beliefs, even if it is possible for us to be mistaken. In fact, since there is no requirement on this fallibilistic understanding of justification that one rule out all possibilities of error, there will be many cases in which one knows that $p$ while realizing, in addition, that epistemic possibilities incompatible with one having knowledge that $p$ remain.

In addition to this fallibilistic construal of justification, epistemologists have stressed, in response to skeptics, that it is not required that one know that one knows $p$ before one can simply know $p$. After all, whether or not I know that $p$ depends on my satisfying whatever the correct analysis of knowl-

6 See Jonathan Kvanvig, "Why Should Inquiring Minds Want to Know?" The Monist 81.3 (1998), 426-451 \& Richard Foley, Working Without a Net (Oxford: Oxford University Press, 1993). We find Descartes' infallibilism undergirded by his use of the Dream and Deceptive Demon Hypotheses in the Meditations.

7 See G. E. Moore, "Certainty" in Sosa, Kim, Fantl, and McGrath, eds., Epistemology: An Anthology, 2nd edition, (Oxford: Blackwell Publishers, 2008), 31-34. 
edge might be. I surely do not need to, in addition, know that I satisfy such an analysis. Consider an analogy from William Alston:

If the object I am eating is made of cardboard, it will not nourish me. But suppose I do not know it is not made of cardboard; it by no means follows just from this lack of knowledge that the object will not nourish me. Its nutrient power, or the reverse, depends on what it is, not on what I do or do not know about it. ${ }^{8}$

And likewise, whether or not we know that $p$ depends on what knowledge is, not on what we do or do not know about it. This insight belongs to the class of problems of levels-confusion in epistemology, and this particular confusion can be found in skeptical arguments of various sorts. ${ }^{9}$ Consider the following:

(1) If I know that I have hands, then I have ruled out the possibility that I am a brain-in-a-vat.

(2) But I have not ruled out the possibility that I am a brain-in-a-vat.

(3) Therefore, I do not know that I have hands.

Though there are many things one might say about the premises of this argument, what's important for our purposes is that the necessary condition on knowing that one has hands, expressed by the consequent of premise (1), exhibits the levels-confusion described earlier. That is, the condition itself requires that one know one satisfies the conditions of knowing. Or yet again, it requires that one know that one knows in order to have knowledge. But the degree of confidence we have that knowing that one knows is required for knowing is very low. In fact, it is much lower than the degree of confidence we have in our belief that we know we have hands. Thus, our confidence in the conclusion's falsity should be much greater than our confidence in the truth of premise (1).

8 William P. Alston, "Levels-Confusion in Epistemology" Midwest Studies in Philosophy 5.1 (1980), 146.

9 See Peter Klein, Certainty: a Refutation of Skepticism (Minneapolis: University of Minnesota Press, 1981) for a nice taxonomy of different types of skeptical arguments. 
So to take stock, there are two fundamental points of general consensus, insofar as there is consensus in philosophy ${ }^{10}$, concerning a good understanding of the nature of knowledge. First, knowledge and the type of justification which contributes to knowledge is fallible. That is, it is consistent with one's knowing that $p$, that one might be wrong. The second point of consensus is like unto the first; namely, that unless one desires to court skepticism, no condition on knowledge which requires someone to first know that they satisfy the conditions on knowledge is permissible. We will call these points of consensus, then, our epistemological desiderata for an adequate doctrine of assurance. But before using our desiderata to construct a plausible doctrine of assurance, let us consider two statements of that doctrine from which we will eventually diverge.

\section{CLASSIC AND CONTEMPORARY STATEMENTS OF ASSURANCE}

As one peruses discussions of assurance in historical theology ${ }^{11}$, it is clear that the concept of assurance is tied closely to the concept of saving faith. ${ }^{12}$ John Calvin's treatment of these concepts was no different, as illustrated in

10 Take the camp of contextualists (Keith DeRose, The Case for Contextualism: Knowledge, Skepticism, and Context, Vol. 1 (Oxford: Oxford University Press, 2006) or Peter Unger, Ignorance: a Case for Skepticism (Oxford: Oxford University Press, 1979) for examples of those who happily demur with the way I have construed fallibilism as epistemically central.

11 See JR Beeke, "Does Assurance Belong to the Essence of Faith? Calvin and the Calvinists” Masters Seminary Journal 5.1 (1994), 43-71 for a more in-depth discussion of this point. My debt to his work should be clear in this section.

12 A brief note on the concept of saving faith. This is a particular species of faith in the same way that swing dancing is a particular species of dance. Not all dance numbers count as instances of swing, and likewise, not all instances of faith count as instances of saving faith. In general (and this diverges in some ways significantly from the concept as it is used by Calvin and Keathley), faith is the orientation of one's life around the pursuit of some sort of ideal or project that is grounded in an underlying cognitive state(s), such as belief, acceptance or even hope (e.g. the belief that God exists and desires to be united with me). I'm undecided on the precise boundaries of this concept. For a helpful discussion which informs the protodefinition of faith just given, see Jonathan L. Kvanvig, "Affective Theism and People of Faith," Midwest Studies in Philosophy 37, ed. by Howard Wettstein (2013), 109-128. Now saving faith in Christian theology, very roughly, consists in the orientation of one's life in accordance with the will of the Christian God. Now what counts as having such an orientation, and how con- 
his formal definition of faith and treatment of the expected behavior of a true believer.

Now we shall possess a right definition of faith if we call it a firm and certain knowledge of God's benevolence toward us, founded upon the truth of the freely given promise in Christ, both revealed to our minds and sealed upon our hearts through the Holy Spirit. ${ }^{13}$

No man is a believer, I say, except he who, leaning upon the assurance of his salvation, confidently triumphs over the devil and death... We cannot otherwise well comprehend the goodness of God unless we gather it from the fruit of great assurance. ${ }^{14}$

Now, while Calvin indeed tied the notions of assurance and saving faith closely together, it is worth noting that he sets aside a place for such concepts as 'weak faith', and other varying degrees of quality for faith. ${ }^{15}$ Allowing for such variation is important since room for serious doubts must be made for any psychologically realistic doctrine of assurance.

If one begins with Calvin's formal definition of faith, however, it becomes clear that an immediate roadblock for any doctrine of assurance is that it is grounded in a "firm and certain knowledge". While the description 'firm and certain' applies perfectly to the promises of God, it is odd that Calvin would apply it to the quality of our human knowledge. And as illustrated with the Moorian sentences in section 2 above, there is an important difference between our concepts of certainty and knowledge more broadly. Certainty (i.e. infallible knowledge) is simply beyond us, and so, it would be best to avoid a requirement of certainty in our doctrine of assurance.

More recently, however, Kenneth Keathley has suggested the following understanding of the relation between assurance and saving faith:

...assurance is the essence of saving faith. The very nature of conversion and regeneration guarantees that certain knowledge of salvation is simultaneous

sistently must one's life fit with the ideal around which one's life is oriented to have saving faith? That is a discussion I could not reasonably weigh into here.

13 John Calvin, Institutes of the Christian Religion. Ed. John T. McNeill, trans. F. L. Battles (Philadelphia: Westminster Press 1960, 3.2.7. Italics are my own.

14 Ibid. 3.2.16.

15 Ibid. 3.2.17-21. 
with being saved. Subsequent doubts and fears may come, but a core conviction about one's relationship with God will remain. ${ }^{16}$

While Keathley's definition explicitly denies the continuation of certainty, and thus, is an improvement over Calvin's statement, certainty still remains as the initial sign of saving faith. And thus, Keathley's understanding of assurance falters for similar reasons to Calvin's. First, the definition of assurance given requires that there be a point of certain knowledge in the life of the genuine believer, and such a requirement is a non-starter given the epistemic limitations of humanity. But second, they seem to have confused the perfect faithfulness of Christ's promise of salvation with our epistemic access to that promise. Such a confusion explains why the language of 'certainty' is so compelling, for who would want to claim that God's faithfulness is less than certain? However, one is not committed to such a blunder upon admission of one's own cognitive fallibility, and thus, the language of 'certainty' is here misguided.

\section{AN EPISTEMOLOGICAL CORRECTIVE}

So we have two different articulations of the doctrine of assurance from Calvin and Keathley. Both emphasize a requirement of certainty for the believer, which is problematic, and both confuse a conviction in the absolute faithfulness of Christ to fulfill his promises to require unwavering certainty of salvation. But clearly, uncertainty regarding one's salvation is consistent with Christ remaining faithful to fulfill his promises, and thus, the second requirement is unnecessary. With this and our fallibilist epistemological desiderata from section 2 in mind, we have the following as our doctrine of assurance:

Fallibilistic Doctrine of Assurance (FDA) - $\mathrm{S}$ has assurance that $\mathrm{S}$ is saved iff $S$ has at least fallible knowledge that $S$ is saved-where $S$ 's fallibly knowing $p$ requires that (i) $\mathrm{S}$ believe $p$, (ii) $p$ is true, and (iii) $\mathrm{S}$ has at least fallible justification for her belief that $p$.

So, according to FDA, it is possible for someone to have assurance of their salvation. In fact, it is likely that many Christians have assurance of salvation according to FDA. After all, Christians will have introspective evidence

16 Keathley 2010, 188. 
that they desire the things of God, they will have evidence that their life and projects have been oriented around the things of God in the past, and they will have good evidence to think it would be surprising for their life to lose its Christocentric orientation.

Of course, having good evidence for one's salvation will not guarantee salvation. This is consistent with FDA, and this is a good thing. Any doctrine of assurance that presumes certainty requires a guarantee that one has the truth. But there are no epistemic guarantees (or at least, optimism for such guarantees seems naïve). And so, this counts in favor of FDA rather than against it.

One road to certainty, highlighted in section 2 , is to learn what the conditions on knowledge are, and then to see whether one satisfies all such conditions with respect to some proposition. Thus, an advocate of Certainty Views of Assurance might object to FDA as follows:

Well, come now, we can identify some sufficient conditions for knowing one is saved. Here's one: God tells you "you will be saved". Suppose then that Mel has a mystical experience in which the angel of the Lord tells her "you will be saved!" She surely knows this is a sufficient condition for salvation. And it seems like she knows she satisfies that condition, so surely, she can have certain assurance of her own salvation.

Even if we grant that God's telling you "you will be saved" is a sufficient condition for salvation (which doesn't seem like too much of a stretch), the above scenario would not be sufficient to grant certain assurance to Mel. What's crucial is that the sort of knowledge Mel has concerning whether or not she satisfies this condition on knowledge of salvation is fallible. To have certain knowledge that she satisfies the condition on knowledge in play, she would further have to rule out any possibility consistent with her having the same evidence but entailing that her mystical experience was non-veridical. For instance, she would need to rule out the possibility that she was dreaming. Of course, she wasn't dreaming, but this doesn't mean she has, or even could, rule out the possibility that she was dreaming. Indeed, her evidence of what transpired would be indistinguishable in the dream scenario from her evidence in the veridical scenario. But then, even in the case where her mystical experience was veridical, she would not able to attain certainty. Thus, because FDA does not carry with it troubling implications of skepticism, I 
conclude that FDA is a superior understanding of the Christian doctrine of assurance (as compared to those considered in section 3 ).

\section{OBJECTION - PRAGMATIC ENCROACHMENT \& THE STAKES OF SALVATION}

There are several possible responses open to anyone with reservations concerning FDA, though most of those objections can, I think, be met. A fairly interesting objection, which I will consider here, originates from philosophers enamored with pragmatic encroachment. According to this philosophical view, knowing is not an entirely epistemic activity. For as the practical stakes of getting things right increase, the requirements for achieving knowledge increase as well. ${ }^{17}$ For illustration, consider the following two cases:

Low Stakes: Bethany is traveling from LA to Rome in a few days. Her mother, who will be giving her a ride, asks her when she will be flying out. Consulting her memory from a week ago, Bethany tells her mother, "Oh, I know the time. The plane leaves at 6:30 P.M.” Bethany's mother accepts what Bethany states as correct without question, and they prepare for the flight.

High Stakes: Bethany is traveling from LA to Rome in a few hours. Her mother, who will be giving her a ride, asks her what exact time she will be flying out. Consulting her memory from a week and a few days ago, Bethany tells her mother, "Oh, I know the time. The plane leaves at 6:30 P.M." Her mother responds, "Have you double-checked? The last thing you want is to be late for an international flight like this one. You'll have to wait at least a day for another one-way trip, but that would throw off your conference plans." Bethany replies, "I guess you're right. I should double-check my ticket before claiming to know the time. It's too important to get it right."

17 There are contextualist variations on this line of thought. I won't deal with every version of pragmatic encroachment here, but my response will be applicable to the general family of views. For a representative sample of pragmatic encroachers, see (i) Jason Stanley, Knowledge and Practical Interests (Oxford: Oxford University Publishing, 2005), (ii) John Hawthorne, Knowledge and Lotteries (Oxford: Oxford University Press, 2003), (iii) Jeremy Fantl and Matthew McGrath, Knowledge in an Uncertain World (Oxford: Oxford University Press, 2009). Also, for an interesting objection from belief-desire psychology, see Jonathan Jenkins Ichikawa, Benjamin Jarvis and Katherine Rubin, "Pragmatic Encroachment and Belief-Desire Psychology," Analytic Philosophy 53.4 (2012), 327-343. 
In these two cases, the only altered factors were pragmatic ones. While I changed the context, I did so without changing either the source or content of Bethany's assertions of knowledge. In Low Stakes, since memory is normally sufficient for knowledge, Bethany knew that her flight would leave at 6:30 P.M. But when in High Stakes she realized she wouldn't have time to check her itinerary again, she ceased to know. And this happened despite Bethany's reliance upon the very same source of knowledge in both contexts. Thus, assuming that our intuitions match Bethany's expressed intuitions in the two cases, it seems that changes in practical stakes lead to changes in knowledge.

Given the above motivation for adopting the view of pragmatic encroachers that knowledge is constrained by pragmatic stakes, the following argument can be made which undermines my claim that FDA (i.e. the Fallibilistic Doctrine of Assurance) is superior to the Certainty Views of Assurance found in section 3:

(1) If Pragmatic Encroachment is true, then the higher the practical stakes for getting the truth of some proposition, $p$, the less likely knowledge of $p$ will be for any agent (Premise)

(2) The practical stakes for knowing that one is saved are as high as practical stakes can possibly be (Premise)

(3) Thus, if Pragmatic Encroachment is true, knowledge that one is saved will be at least as unlikely as knowledge of any other proposition (from $1 \& 2$ )

(4) If knowledge of a proposition is at least as unlikely as knowledge of any other proposition, then no one knows that proposition (Premise)

(5) Therefore, if Pragmatic Encroachment is true, then no one knows that they are saved (from $3 \& 4$ )

(6) FDA will be an improvement on Certainty Views of Assurance only if the number of people with assurance increases on FDA (Premise)

(7) Pragmatic Encroachment is true (Premise) 
(8) Therefore, FDA is not an improvement over Certainty Views of Assurance (from 5-7)

What are we to make of this argument? The core of the argument is this: if Pragmatic Encroachment is true, then no one will have assurance, even on a Fallibilistic Doctrine of Assurance. Thus, FDA will not be any better than Certainty Views. Why? Because the entire motivation for adopting FDA was based on a problem for Certainty Views; namely, they rule out the possibility of assurance for everyone. But FDA will share this problem if Pragmatic Encroachment is true. Thus, the proponent of FDA must provide a plausible explanation of the interplay between practical stakes and knowledge that (i) serves as an alternative to Pragmatic Encroachment explanations \& (ii) does not allow practical stakes to preclude knowledge, even when the stakes are high. In doing this, then, they will provide a reason to reject, or at least doubt, premise (7).

The first thing to notice about Pragmatic Encroachment is that the view purports to be the best explanation of the sorts of intuitions involved in the Low Stakes and High Stakes cases above. ${ }^{18}$ That is, pragmatic encroachers think the best explanation of Bethany's reported change in knowledge is that pragmatic stakes are part of the nature of knowledge. And since the stakes are very high in the second case, Bethany ceases to know that her flight leaves at 6:30 P.M. I will offer two responses to this interpretation of Bethany's predicament.

Clearly, the above cases are entirely consistent with the falsity of Pragmatic Encroachment. An alternative explanation is fairly close at hand, for even if Bethany knows that her flight leaves at 6:30 P.M. in both cases, she may not be warranted in asserting that she knows this. Perhaps she knows but, in addition, there are higher grades of knowledge which are necessary for warranted assertability. Thus, she may have knowledge, just not a high enough grade of knowledge to pass it on to her mother via testimony. ${ }^{19}$ And thus on this interpretation, practical stakes will only increase the necessary grade of knowledge for warranted assertability. They will not prohibit knowledge itself.

18 Stanley 2005, 3-4.

19 See Jessica Brown, "Contextualism and Warranted Assertability Manoeuvres" Philosophical Studies 130.3 (2006), 407-435 for a discussion of some views along these lines. 
My preferred response to premise (7), however, is more general. ${ }^{20}$ In ordinary contexts, regular English speakers make two false assumptions about knowledge. The first false assumption, which we've already seen, concerns the nature of knowledge; namely, that knowledge requires certainty. The second false assumption concerns the value of knowledge. The assumption is this: the value of knowledge is largely exhausted by the fact that it always enables one to act.

But why should we think that knowledge is always actionable in this way? Indeed, apparently pointless truths seem to lack actionability even though they are quite knowable. ${ }^{21}$ Consider the following example of an apparently pointless truth: there are, very roughly, seven quintillion five hundred quadrillion grains of sand partially composing the earth. ${ }^{22}$ This information is interesting, but even if true, it is not actionable. Or at least, it is not actionable in any obviously uncontrived sense. And thus, it has little to no instrumental value.

With this observation in hand concerning why we think we value knowledge, I can offer a plausible alternative explanation for the intuition changes involved in Low Stakes and High Stakes. We tend to seek out knowledge that we can act on. Thus, it is common for us to develop myopia to the idea that there is non-instrumental value one might assign to knowledge; that is, value that is independent of what it gets us. But then, we buy into the idea that knowledge is by its nature actionable, and thus, if we are unable to act on the content of some apparent knowledge, we intuitively judge that we must not really know what we thought we knew. Thus, at bottom, the Pragmatic Encroachment intuitions involved in the cases above exhibit a confusion for what we value in knowledge as essential to knowledge (i.e. part of its nature). And thus, we take this misconstrual of the nature of knowledge as indica-

20 See Jonathan Kvanvig, "Against Pragmatic Encroachment" Logos and Episteme: An International Journal of Epistemology 2.1 (2011), 77-85.

21 Ernest Sosa, "For the Love of Truth?" in Zagzebski and Fairweather, eds., Virtue Epistemology: Essays on Epistemic Virtue and Responsibility (Oxford: Oxford University Press, 2000), 49-62.

22 Robert Krulwich, "Which is Greater, the Number of Sand Grains on Earth or the Number of Stars in the Sky?" (National Public Radio, September 18, 2012). <http://www.npr. org/sections/krulwich/2012/09/17/161096233/which-is-greater-the-number-of-sand-grainson-earth-or-stars-in-the-sky>. 
tive of a failure to know, which in the cases above is false. In both instances, Bethany knows. She just can't act on that knowledge in both cases.

While a more thorough response to Pragmatic Encroachment is desirable, the two replies described above-i.e. the one relying on warranted assertability and the other relying on a confusion of what gives knowledge value with what knowledge is-are sufficient to call premise (7) into doubt. As a result, the argument from Pragmatic Encroachment against the superiority of a Fallibilistic Doctrine of Assurance over Certainty Views of Assurance remains unconvincing.

\section{CONCLUSION}

In this paper, I argued that, given a plausible Fallibilistic Doctrine of Assurance (FDA), knowledge of salvation is attainable for Christians. To that end, I presented some anti-skeptical motivations for adopting fallibilism, and after looking at two different formulations of a doctrine of assurance by John Calvin and Kenneth Keathley, I presented an alternative formulation of the doctrine of assurance, $F D A$, informed by those preceding epistemological considerations. Once I did this, I presented and responded to an objection from pragmatic encroachment. While this objection purported to demonstrate that FDA was no better than the Certainty Views of Assurance represented by Calvin and Keathley, the intuitions in favor of Pragmatic Encroachment could not be reasonably sustained. Consequently, as it stands, FDA provides sufficient grounds for the elect to indeed have knowledge of their status as elect, in order that they might assent to the witness of the author of Hebrews, who writes,

Let us draw near with a true heart in full assurance of faith... Let us hold fast the confession of our hope without wavering, for he who promised is faithful (Hebrews 10:22-23 ESV). 